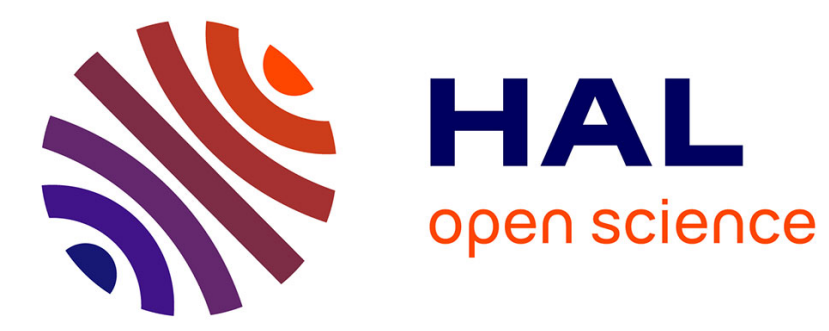

\title{
Multielectron Excitations in X-Ray Absorption Spectra of $\mathrm{KOH}$
}

\author{
M. Takahashi, A. Ishida, S. Emura, D. Osawa, K. Yamaguchi, Y. Ito, T.
}

Mukoyama

\section{- To cite this version:}

M. Takahashi, A. Ishida, S. Emura, D. Osawa, K. Yamaguchi, et al.. Multielectron Excitations in X-Ray Absorption Spectra of KOH. Journal de Physique IV Proceedings, 1997, 7 (C2), pp.C2-1265C2-1266. 10.1051/jp4:19972225 . jpa-00255299

\section{HAL Id: jpa-00255299 https://hal.science/jpa-00255299}

Submitted on 1 Jan 1997

HAL is a multi-disciplinary open access archive for the deposit and dissemination of scientific research documents, whether they are published or not. The documents may come from teaching and research institutions in France or abroad, or from public or private research centers.
L'archive ouverte pluridisciplinaire HAL, est destinée au dépôt et à la diffusion de documents scientifiques de niveau recherche, publiés ou non, émanant des établissements d'enseignement et de recherche français ou étrangers, des laboratoires publics ou privés. 


\title{
Multielectron Excitations in X-Ray Absorption Spectra of KOH
}

\author{
M. Takahashi, A. Ishida, S. Emura, D. Osawa*, K. Yamaguchi*, Y. Ito* and T. Mukoyama* \\ The I.S.I.R., Osaka University, Mihogaoka 8-1, Ibaraki, Osaka 567, Japan \\ * Institute for Chemical Research, Kyoto University, Uji, Kyoto 611, Japan
}

\begin{abstract}
The X-ray absorption spectra have been measured near $K$ edge of a crystalline $K O H$. After the subtraction of XAFS oscillation, several features caused by multielectron transitions suggested on noble gases were detected on $\mathrm{K}$ in solid phase and analyzed by the use of the shakeup and shakeoff probabilitics. The [1s2p], [1s3s], and [1s3p] transition onsets have been identified in the compound.
\end{abstract}

\section{INTRODUCTION}

Photoabsorption of atoms has been generally treated as a single-electron excitation process. However, the existence of the multielectron excitation process, where the removal of a core electron by photoabsorption causes excitation of additional electrons in the same atoms, has been known in x-ray absorption spectra for a long time [1]. With the advent of synchrotron radiation facilities, in several recent years, this process has been studied extensively in various gases [2 7]. It was pointed out by Kodre and co-workers that for solid targets it is difficult to identify weak transitions corresponding to multielectron excitation in $x$-ray absorption spectra. The reason is that in condensed matter, the oscillation due to the $x$-ray absorption fine structure masks small signals in the enegy region where multiple electron excitation ([KL]) occurs and this is physically due to the spread of the absorption thresholds over a large range of energies caused by the many multiplets produced by the open $d$ shell [8]. The [KM] transitions within the extended XAFS (EXAFS) oscillations, together with $x$-ray absorption near edge structure, have been recognized in crystalline samples $[9,10]$ and the $[\mathrm{KL}]$ double-electron transition edges of $\mathrm{Si}, \mathrm{P}, \mathrm{S}$, and $\mathrm{Cl}$ in compounds were recognized in $x$-ray absorption spectra by Filipponi et al. [11]. The understanding of the transition processes involved in multielectron excitations is very important to interpret XAFS [8 13]. These processes have therefore received a special attention in XAFS analysis.

In this study, the X-ray absorption spectra have been measured above $\mathrm{K}-K$ edge in a crystalline $\mathrm{KOH}$ in order to elucidate the contribution of the multiexcitation to them.

\section{EXPERIMENTAL}

The X-ray absorption spectra for $\mathrm{KOH}$ were measured using the beam line BL-7C of the Photon Factory Ring in National Laboratory for High Energy Physics, KEK, Tsukuba, with $2.5 \mathrm{GeV}$ positrons at a circular current of 260 - $360 \mathrm{~mA}$ for $24 \mathrm{~h}$. The harmonic content of the beam at this low energy was so great that the residual harmonic content contributed sufficient nonlinearities to cause significant noise. Therefore, it was necessary to minimize the harmonic content of the incoming beam. The radiation was detuned with a $\mathrm{Si}$ (111) double - crystal and focussed using the quartz mirror to reduce the harmonic content. The calculated energy resolution (combined intrinsic crystal resolution and vertical angular divergence of the beam) was less than $1 \mathrm{eV}$ at the $\mathrm{K}-K$ edge. The samples were prepared by mixing $\mathrm{KOH}$ solution and polyvinyl alcohol by heating, and the foils were formed for the absorption experiment. Several layers were stacked to obtain a sample with a suitable thickness of absorption length. Data were collected at room temperature.

\section{RESULTS \& DISCUSSION}

As shown in Fig. 1, the evidence of the multielectron excitations above the K-K edge can be obtained by subtracting the XAFS oscillations from the observed absorption spectra. The threshold onsets occur at $17.06 \mathrm{eV}, 45.63 \mathrm{eV}$, and $333.7 \mathrm{eV}$ which appear to be due to the multiexcitation transition. For all the edges studied below, we comare the position of the step to that predicted by the $\mathrm{Z}+1$ approximation model [10]. This model gives $25.4 \pm 0.4 \mathrm{eV}, 43.7 \pm 0.4 \mathrm{eV}, 346.4 \pm 0.4 \mathrm{eV}, 350 \pm 0.4 \mathrm{eV}$, and $437.8 \pm 0.4 \mathrm{eV}$ for the $\mathrm{M}$ and $\mathrm{L}$ levels, respectively, using the the $\mathrm{x}$-ray atomic energy level [14] of $\mathrm{K}$ to calculate the 
energy of the second core hole. It is found that these values sre consistent with [1s $3 \mathrm{p} 1 / 2,3 / 2],[1 \mathrm{~s} 3 \mathrm{~s}],[1 \mathrm{~s} 2 \mathrm{p} 1 / 2,3 / 2]$, and [1s $2 \mathrm{~s}]$ double electron transitions. [1s2p1/2] and [1s2p3/2] transitions can not be distingushed in the $x$-ray absorption experiment. These are in good agreement with the predictions of the $\mathrm{Z}+1$ model as listed in Table 1 .

In addition to the absorption edges described above, we found other transitions as seen in Fig. 1. These transitions can not yet be identified for the calculated shake processes in Table 1. This may be due to the chemical environment of the photo absorber atom (ion) [15].

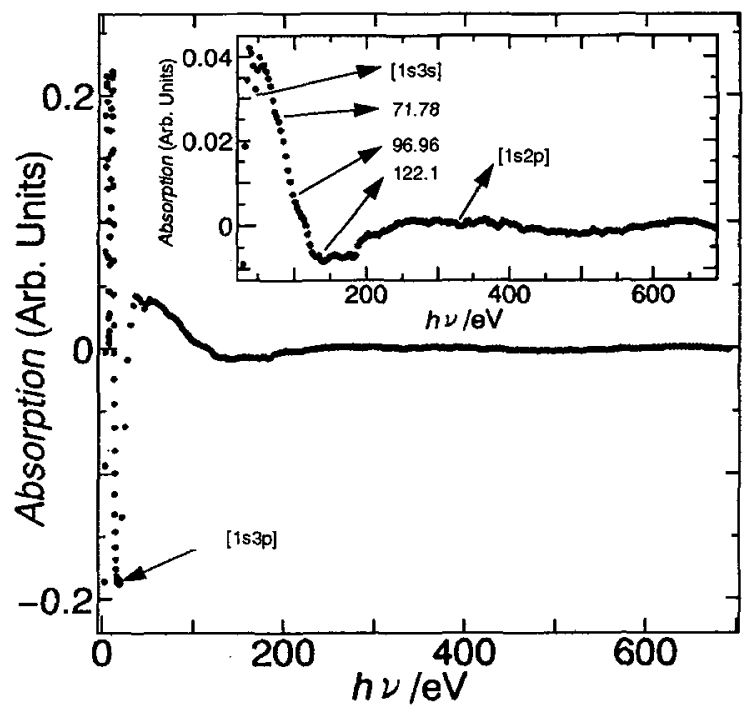

Table 1. Electron configuration and energies of two-electron transitions for $\mathrm{K}$ atom. The energies $(\Delta \mathrm{E})$ are given relative to the $K$ edge of $\mathrm{K}$ atom.

\begin{tabular}{|l|l|l|}
\hline & \multicolumn{2}{|c|}{$\Delta \mathrm{E}(\mathrm{eV})$} \\
\hline Configuration & $\mathrm{Z}+1$ & measured \\
\hline$[1 \mathrm{~s} 2 \mathrm{~s}]$ & $437.8 \pm 0.4$ & - \\
\hline$[1 \mathrm{~s} 2 \mathrm{p}]$ & $346.4 \pm 0.4$ & 333.7 \\
& $350.0 \pm 0.4$ & \\
\hline & & 122.1 \\
\hline & & 96.9 \\
\hline & & 71.8 \\
\hline$[1 \mathrm{~s} 3 \mathrm{~s}]$ & $43.7 \pm 0.4$ & 45.6 \\
\hline$[1 \mathrm{~s} 3 \mathrm{p}]$ & $25.4 \pm 0.4$ & 17.1 \\
\hline
\end{tabular}

Fig.1. The x-ray absorption spectra extracted both XAFS oscillation and photoelectron cross section [16] of $\mathrm{K}$ atom. The energy is relative to $\mathrm{K}-K$ edge and the arrows indicate the energy position predicted by the $\mathrm{Z}+1$ approximation.

\section{Acknowledgements}

The authors would like to express their thanks to Mr.M.Kakuichi for the preparation of the sample cells. This work has been performed under the approval of the Photon Factory Program Advisory Committee (Proposal No. 93G-174).

\section{References}

[1]Wuilleumier F.. J.Phys.(Paris) Collog.32(1971)C4-88.

[2]Armen G.B.,Aberg T.,Karim K.,Levin J.,Crasemann B.,Brown G.,Chen M., and Ice G., Phys.Rev.Lett.54 (1985) 182.

[3]Ito Y.,Nakamatsu H.,Mukoyama T.,Omote K.,Yoshikado S.,Takahashi M., and Emura S., Phys.Rev.A46 (1992) 6083.

[4]Schaphorst S.,Kodre A.,Ruscheinski J.,Crasemann B.,Chen M.,Tulkki J.,Aberg T.,Azuma Y., and Brown G., Phys. Rev.A47 (1993) 1953.

[5]Deslattes R.D., LaVilla R.E., Cowan P.L., and Henins A., Phys.Rev.A27 (1983) 923.

[6]Bernieri E. and Burattini E., Phys.Rev.A35 (1987) 3322.

[7]Kuetgens U. and Hormes J., Phys.Rev.A44 (1991) 264.

[8]Chaboy J. and Tyson T.A., Phys. Rev.B49(1994) 5869.

[9]Stern E., Phys.Rev.Lett. 49 (1982) 1353.

[10]Li G., Bridges F., and Brown G., Phys.Rev.Lett. 68 (1992) 1609.

[11]Filipponi A., Tyson T., Hodgson K., and Mobilio S., Phys.Rev.A48 (1993) 1328.

[12]Ito Y., Mukoyama T., Emura S., Takahashi M., Yoshikado S., and Omote K., Phys.Rev.A51 (1995) 303.

[13]D'Angelo P., Nolting H.-F., and Pavel N.V., Phys.Rev.A53 (1996) 798.

[14]Bearden J.A. and Burr A.F.. Rev.Mod.Phys.39 (1967) 125.

[15]D'Angelo P.,Cicco A.D., and Pavel N.V.. Phys.Rev.A47 (1993) 2055.

[16]McMaster W.H.,Del Grande N.K.,Mallet J.H., and Hubbcll J.H., Lawrence Livermore Laboratory Report No.UCRL-50174 (1969) (unpublished). 